\title{
PREEMPTIVE EPIDURAL S-KETAMINE OR KETAMINE IN POSTINCISIONAL PAIN IN DOGS
}

\author{
DUQUE, J.C. ${ }^{1}$; FARIAS, A. ${ }^{2}$; OLESKOVICZ, N. ${ }^{1}$; ALMEIDA, R.M. ${ }^{1}$; VALADÃO, C.A.A. ${ }^{3}$ \\ ${ }^{1}$ Mestrando do Programa de Pós-Graduação em Cirurgia Veterinária, UNESP/Jaboticabal; \\ ${ }^{2}$ Doutorando do Programa de Pós-Graduação em Cirurgia Veterinária, UNESP/Jaboticabal; \\ ${ }^{3}$ Anestesiologia Veterinária, DCCV/UNESP/Jaboticabal - valadao@fcav.unesp.br.
}

Preemptive administration of analgesic drugs can reduce the postincisional pain and enhance recovery period. Ketamine, a non-competitive NMDA receptor antagonist prevent central sensitization and decrease secondary hyperalgesia after skin incision. S-ketamine was developed recently and has been useful in postoperative pain treatment in children. The aim of this study was therefore to evaluate the preemptive effect of epidural S-ketamine or ketamine administration in dogs. Eighteen mixed breed dogs, $3 \pm 1$ years old, males or females, weighting $12 \pm 3 \mathrm{~kg}$, divided into G1 (S-ketamine, $n=6$ ), G2 (ketamine, $n=6$ ) and $\mathrm{G} 3$ (saline, $n=6$ ) were used. After propofol (5 mg/kg/) IV anesthesia, an epidural Tuohy (16G) needle was inserted at the lombo-sacral space and an epidural catheter (16G) was advanced 5 $\mathrm{cm}$ cranially into epidural space. After catheter placement was injected S-ketamine $(0,62 \mathrm{mg} / \mathrm{kg})$ to $\mathrm{G} 1$, ketamine $(0,62 \mathrm{mg} / \mathrm{kg})$ to $\mathrm{G} 2$ or saline to $\mathrm{G} 3$, all diluted in saline to final volume of $0,3 \mathrm{ml} / \mathrm{kg}$. Five minutes after of epidural injection a $2 \mathrm{~cm}$ incision was made in the paw and closed with simple interrupted nylon suture. Respiratory $(R R)$ and heart $(H R)$ rates, temperature $(T)$, sedation grade $(S)$ and mechanical hyperalgesia $(\mathrm{MH})$, by vonFrey filaments, were evaluated at 15, 30, 45, 60, 75, 90 minutes, 2, 4, 6, 8, 12, and 24 hours after the epidural injection. Data were analised by Kruskal-Wallis test for non parametric values and Tukey test for parametric values. There were no significant differences in RR, HR, T and $S$ between groups. Motor blockade and ataxia of hindlimbs were observed between 18 and 45 minutes, and between 18 and 26 minutes in the $\mathrm{G} 1$ and $\mathrm{G} 2$ animals respectively. It was observed that mechanical force applied to obtain an painful response, in the $\mathrm{G} 1$ and G2 animals was increased between 60 to 90 minutes and between 45 minutes to 12 hours, respectively, when compared with G3 animals. It was concluded that epidural ketamine reduced postincisional pain for a more prolonged time (12 hours) that Sketamin (1.5 hours), in dogs.

Key Words: Ketamine, S-Ketamine, Preemptive, Pain, dogs. 